\title{
Transforming Brownfields from Deteriorated to Revitalized Space - the Role of Local Urban Community
}

\author{
Aseel Essam Abu Zayed ${ }^{1}$, Nabeel Yosuf Al-Kurdi ${ }^{1 *}$ \\ 1 Department of Architecture, Faculty of Engineering, the University of Jordan, Amman, Jordan \\ * Corresponding author's e-mail: Arch_aseel_abuzayed@hotmail.com
}

\begin{abstract}
This research aims at introducing a clear, sustainable framework for brownfield regeneration that focuses on the role of community in urban regeneration. The town of Al-Fuheis, Jordan, is losing its shine under clouds of dust and chemical emissions. It needs regeneration so that social and economic struggles can be simultaneously addressed through innovative regeneration. In order to reach this goal, a qualitative analysis was presented to introduce the general framework of brownfield regeneration. The structure of the framework depends on the researcher's interpretation. Purposive sampling was used in this part of the study to involve the local community in taking decisions concerning regeneration. Their decisions must be considered during the master plan development. The brownfield regeneration model is summarized in a clear diagram. The results of a questionnaire analysis show the effective role of community to participate in urban regeneration. Applying the brownfield regeneration framework enhances the social, environmental, and economic value.
\end{abstract}

Keywords: brownfield; sustainable urban regeneration; framework; urban values; local community

\section{INTRODUCTION}

The term "brownfield" is opposite of "greenfield" (Hua \& Kang, 2007). An urban planner defined brownfield land as an abandoned site that has various negative impacts on the surrounding context (Doerle, 2012). There is no standard definition for the term "brownfield". According to the United States Environmental Protection Agency (EPA), a brownfield is an idled, abandoned, and contaminated site that has become a major problem to the urban fabric by reducing the environmental quality and human health. Furthermore, brownfields contribute to the increasing crime rates (Walker, 2008). The EPA introduced brownfields as a derelict industrial complex, which is difficult to reuse because of the environmental contamination (FATEMI \& RAHMAN, 2015). Nowadays, there are many definitions by various institutions, but the most common is the one stated by the Contaminated Land Rehabilitation Network for Environmental Technologies. It defined a brownfield as a site that has been influenced by the previous use or by the surrounding land uses, abandoned, unexploited and is suffering from contamination problems (Folić \& Perovic, 2012). Brownfield sites are distinguished by their size, previous use, and location (Doerle, 2012). Başkaya (2010), in his paper entitled "Ways to Sustainable Brownfield Regeneration in Istanbul," classified the brownfield sites in Istanbul into four constant main categories and variable minor categories based on their position within the urban fabric of the city: the function that the brownfield performs, its temporal value within a specific period, and the memories surrounding the place. Brownfields have a dangerous impact on the urban context. According to Berman \& Forrester (2013), the four main areas negatively affected by brownfields include health, society, environmental risk, and construction. Another researcher summarized the economic disadvantages of brownfields (Bartsch, 2006). The regeneration of abandoned sites has been a remarkable idea in past years and an important source of conflict since 
the 1980s. However, decision makers continue to be concerned about regeneration and enhancing the quality of life (Loures \& Panagopoulos, 2007). According to Glöckner \& Pahlen (2004), sustainable brownfield regeneration involves the management, renewal, and reuse of brownfields in a useful manner to meet the current needs of people and those of their descendants in terms of a suitable environment, strong institutions, economic growth, and social interaction. The term "brownfield regeneration" is mainly related to sustainable urban development. Both ideas are similarly developed around social, environmental, and economic issues (Mehdipour \& Nia, 2013). Brownfield reuse for sustainable urban regeneration concerns three different issues (Doerle, 2012):

- revitalization as a social issue,

- remediation as an environmental issue, and

- reintegration as an economic issue.

The sustainable urban regeneration provides a social benefit by encouraging the community's responsibility, improving the quality of life that enhances social issues, preventing local citizens' immigration which can cause a lack of urban growth, creating more sight attraction places (Mehdipour \& Nia, 2013), decreasing crime and providing local facilities.

Al-Fuheis is known as a small agricultural area with beautiful green mountains. Al-Fuheis was divided into two main zones: the historic zone (Balad) and the newer uptown zone (Alali). Alali was built as a result of population growth in the 1950s and the construction of a cement factory. Before 1951, when the factory was established, the site was agricultural land. In 1985, the factory was taken from the Southern Cement Company. By 1998, the government sold around $33 \%$ of its shares to Lafarge Group, a cement manufacturer. The company was privatized, and by 2010 , Lafarge Group owned $50.2 \%$ of its shares. In 2016, in response to a complaint by the citizens of Al-Fuheis, the factory ceased operation (Lafarge, 2017).

Nowadays, the factory is becoming the main source of contamination for Al-Fuheis and is a major challenge influencing the health of its citizens. It was the main cement company in Jordan and the largest factory in Jordan's history (Lafarge, 2017).

\section{METHODOLOGY}

The structure of the framework depends on the researcher's interpretation and observations, in addition to a theoretical investigation and a descriptive analysis of the proposed site. In this phase, experts and the local community prepare the alternatives and three values of regeneration (social, environmental, and economic) for evaluation. Purposive sampling is conducted in this part to involve the local community in making decisions about regeneration. Their decisions are considered in the evaluation. After the analysis and evaluation are completed, the proposed master plan based on suitable alternatives is drawn.

\section{Applying the Sustainable Framework for Brownfield Regeneration to the Al-Fuheis Cement Factory}

Al-Fuheis is losing its shine under the clouds of dust and chemical emissions. It needs regeneration so that the social, ecological, and economic struggles can be simultaneously addressed through collaborative action and innovative regeneration. The devised regeneration framework is applied to solve the dangerous effects of the cement factory and convert for appropriate uses that serve the needs of the Al-Fuheis population. The framework was divided into three main phases: pre-urban regeneration, during urban regeneration, and long-term operation.

\section{Pre-Urban Regeneration}

Before starting the urban regeneration process, it is essential to have a clear plan by introducing an organization structured to facilitate participation and define the role of each participant in the regeneration process (see Table 1).

\section{The role of local community in urban regeneration}

The local community partnership plan provides a chance for the local community in making decisions in the Brownfield regeneration. It identifies how the society can plan their city or neighborhood. It is a combination of the residents, monarchy owners, business owners and visitors. Each one has diverse needs. The local community is involved in choosing the appropriate usage for the site, implementing, and evaluating it. 
Table 1. Members' organization structure

\begin{tabular}{|c|c|c|c|}
\hline \multirow{2}{*}{ Member } & \multicolumn{3}{|c|}{ Tasks } \\
\hline & Phase (1) & Phase (2) & Phase (3) \\
\hline Government & $\begin{array}{l}\text { - Introduce the project. } \\
\text { - } \text { structure. } \\
\text { - Inform the locals. } \\
\text { - Identify the funders of } \\
\text { the project. }\end{array}$ & $\begin{array}{l}\text { - Provide sufficient data about } \\
\text { the brownfield site for as- } \\
\text { sessment. } \\
\text { - Grant financial supports. } \\
\text { - } \text { Monitor all of the stages. } \\
\text { - Evaluate. }\end{array}$ & $\begin{array}{l}\text { - Provide awareness } \\
\text { lectures. } \\
\text { - Distribute brochures } \\
\text { about the importance } \\
\text { of preserving our magi- } \\
\text { cal site. } \\
\text { - Launch publicity and } \\
\text { offer various mainte- } \\
\text { nance workshops for } \\
\text { the community. }\end{array}$ \\
\hline Professional group & $\begin{array}{l}\text { All of the profession- } \\
\text { als in the first phase } \\
\text { are informed about the } \\
\text { project and prepared } \\
\text { for the next phase. }\end{array}$ & & $\begin{array}{l}\text { - Plan a schedule for the } \\
\text { planned maintenance. }\end{array}$ \\
\hline Environmental experts & & $\begin{array}{l}\text { - Assess the contamination. } \\
\text { - Remediate the site and clean } \\
\text { it up. }\end{array}$ & $\begin{array}{l}\text { Participate in the soft } \\
\text { landscape mainte- } \\
\text { nance. }\end{array}$ \\
\hline Planners & & $\begin{array}{l}\text { - Analyze the spatial context. } \\
\text { Study the alternatives for the } \\
\text { land use and enhancement } \\
\text { values. } \\
\text { - Identify the new land uses } \\
\text { of the site according to the } \\
\text { evaluation. } \\
\text { - Develop the site and propose } \\
\text { the design principle master } \\
\text { plan, land use plans, and } \\
\text { detailed master plan. }\end{array}$ & $\begin{array}{l}\text { - Participate in the hard } \\
\text { landscape mainte- } \\
\text { nance. }\end{array}$ \\
\hline Architects & & $\begin{array}{l}\text { - Assess the physical struc- } \\
\text { ture. } \\
\text { - Renovate the existing build- } \\
\text { ing. } \\
\text { - Participate in the design } \\
\text { principle master plan. }\end{array}$ & $\begin{array}{l}\text { Participate in the build- } \\
\text { ing maintenance. }\end{array}$ \\
\hline Landscape designers & & $\begin{array}{l}\text { Design the landscape of the } \\
\text { site. } \\
\text { - Participate in the design } \\
\text { principle master plan. }\end{array}$ & $\begin{array}{l}\text { Participate in the soft } \\
\text { landscape mainte- } \\
\text { nance. }\end{array}$ \\
\hline Project manager & & $\begin{array}{l}\text { - Identify the time schedule. } \\
\text { - } \text { Monitor all of the stages. } \\
\text { - Follow up with the members. }\end{array}$ & $\begin{array}{l}\text { Structure the mainte- } \\
\text { nance schedule and } \\
\text { follow up. }\end{array}$ \\
\hline Economic expert & & $\begin{array}{l}\text { - Study the feasibility of the } \\
\text { project. } \\
\text { - Follow up with the project } \\
\text { funding. } \\
\text { - Suggest various solutions to } \\
\text { increase investment in the } \\
\text { project. }\end{array}$ & $\begin{array}{l}\text { Calculate the annual } \\
\text { maintenance budget. }\end{array}$ \\
\hline Local community & $\begin{array}{l}\text { Inform the local com- } \\
\text { munity are informed, } \\
\text { and give them permis- } \\
\text { sion to protest. }\end{array}$ & $\begin{array}{l}\text { - Participate in cleaning up the } \\
\text { deteriorated site. } \\
\text { - Participate in the decisions } \\
\text { on transformation and reuse. }\end{array}$ & $\begin{array}{l}\text { - Participate in the main- } \\
\text { tenance of the site and } \\
\text { the building. }\end{array}$ \\
\hline
\end{tabular}


Mohamed (2011), in his thesis entitled "Public Participation in Urban Development Process through Information and Communication Technologies", explained the local community participation stairs by Kingston. Those steps have been modified by the researcher:

1. The community prerogative to be informed:

The first phase in participation is that the society would be aware of the regeneration issues on their urban context.

\section{Informing the community:}

The authority provides an action plan to inform the community, but in this phase they do not have the permission to respond.

\section{The community prerogative to protest:}

In this phase the community members have the option to agree or not, but they do not have the ability to edit it.

4. The local participation in the regeneration process (Structuring the community member group)

This step features a strong level of the community involvement in making the decision. The group of community is structured. This group represents the community's voice. They may include residents, business owners and local planners.

*The following steps of the community participation engage in the next phase of regeneration framework, (During Urban Regeneration Phase).

\section{Local community participating in determining} the new land use:

The community participates in choosing the appropriate new land use of the deteriorated site. In this step, questionnaires are distributed and interviews take place.
6. Local community participating in the project implementation:

This phase represents a strong relationship between the community and the proposed project. The participation of the community enhances the feeling of belonging and interest for the place. Figure 1 represents the local community participation stairs.

The next stage is to start identifying the brownfield site at Al-Fuheis, which helps in the subsequent stages when dealing with the site and choosing the appropriate strategies for regeneration. The cement factory, located on industrial heritage sites, imparted negative memories on the local community. The area of the project is 1880 dunam, although nowadays only one manufacturing lane is used.

After the participating members had been chosen, the organization structure for the first phase is published and the Brownfield site is identified. Different awareness workshops take place at this phase to increase the awareness and responsibility for each member, especially the local community. At the end of the phase, the task schedule is written to the next phase. Figure 2 shows the organization structure for the first phase.

\section{During Urban Regeneration}

The second phase is the most important one in the process of regeneration. It begins with an assessment of the environmental issues by qualified experts to identify the extent of the contamination and an evaluation of the physical structure to identify appropriate strategies. Finally, the redevelopment for the site takes place. Different land use scenarios are presented to the local community, planners, and developers to choose the suitable function for the recycled site. Afterwards,

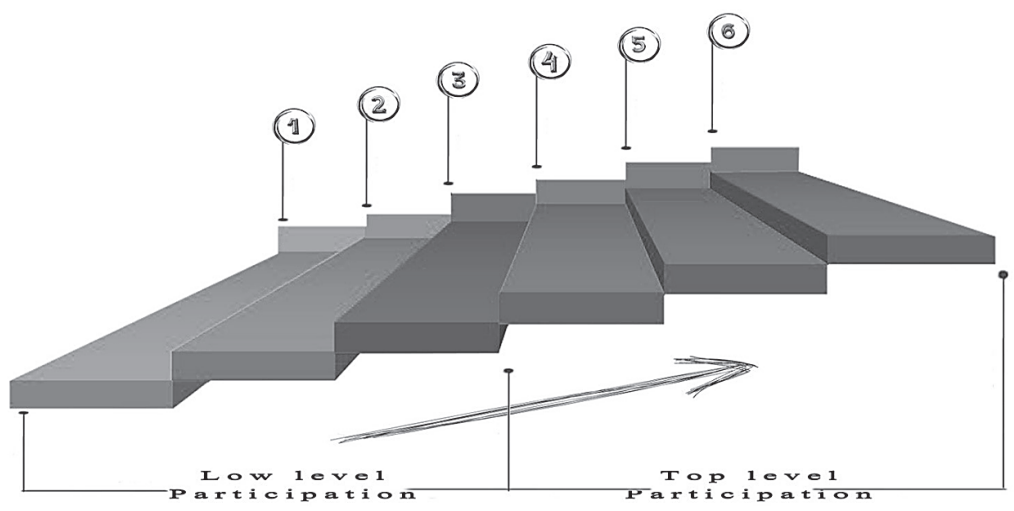

Figure 1. The local community participation stair 
the proposed master plan is published and the implementation begins. The local community is involved in this phase involving construction of the project, which promotes the feeling of belonging.

- Assess the Current Position and Provide SWOT Analysis

The assessment process is limited to the microscale. It contains two assessments: the contamination assessment and the physical assessment.

The physical assessment determines the existing condition of the structure. It helps the designer to make the right decision in the next step (see table 2).

The SWOT analysis of the site is presented (Table 3) to show the strengths, weaknesses, opportunities, and threats of certain dimensions for the brownfield site. In this research, the focus is on three other dimensions: environmental, economic, and social.

\section{The new land use alternatives}

According to the observations in the SWOT analysis, many land use scenarios have been suggested, and their impacts on the brownfield values have been explained. This study emphasizes only three values: social, environmental, and economic, which were mentioned in the definition of urban regeneration. The arrangement of the values is descending from the most affected to the least affected.

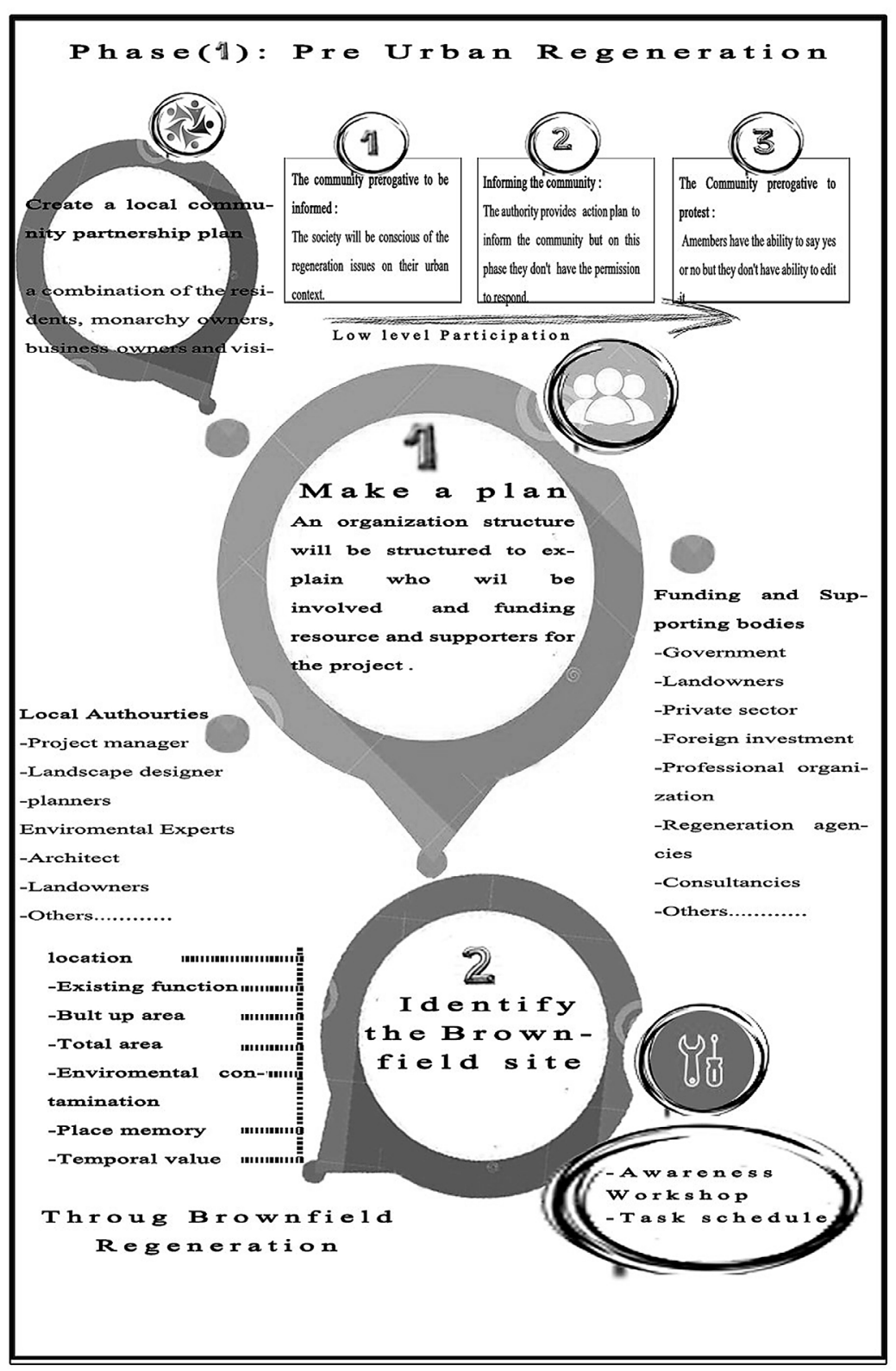

Figure 2. The first phase (Pre Urban Regeneration) 
Table 2. Physical assessment

\begin{tabular}{|c|c|}
\hline Structure name & Physical sssessment \\
\hline Pozzolana storage (55) & $\begin{array}{l}\text { - Visually pleasing, needs general cleaning } \\
\text { - Needs paint work }\end{array}$ \\
\hline Cement silos and bulk loading (49) & $\begin{array}{l}\text { - Visually pleasing, freestanding silos } \\
\text { - Can be seen from a distance, clear in the skyline } \\
\text { - Attached circulation elements }\end{array}$ \\
\hline Clinker silos (8) & $\begin{array}{l}\text { - Not visually pleasing, needs extensive cleaning } \\
\text { - Barely seen from a distance }\end{array}$ \\
\hline Control building (10) & $\begin{array}{l}\text { - Not visually pleasing } \\
\text { - Needs extensive paint and plaster work }\end{array}$ \\
\hline Packing plant 1.1 (7) & $\begin{array}{l}\text { - Good quality of interior spaces, workable structure } \\
\text { - } \text { - Broken visually pleasing, needs extensive paint work } \\
\text { - }\end{array}$ \\
\hline Packing plant $1.2(7)$ & $\begin{array}{l}\text { - Good quality of interior spaces, workable structure } \\
\text { - } \text { Brot visually pleasing, needs extensive paint work } \\
\text { - Brostos and windows, very dusty }\end{array}$ \\
\hline Cement silos (48) & $\begin{array}{l}\text { - Physical assessment, visually pleasing } \\
\text { - Needs excessive paint work, needs general cleaning } \\
\text { - Attached circulation elements }\end{array}$ \\
\hline Cement silo (6) & $\begin{array}{l}\text { - Visually pleasing, freestanding silo } \\
\text { - Attached circulation elements, clearly seen on the skyline } \\
\text { - Can be seen from a distance, needs general cleaning }\end{array}$ \\
\hline Packing plant (6) & $\begin{array}{l}\text { - Visually pleasing, needs general cleaning } \\
\text { - Very dusty, broken asbestos } \\
\text { - Quality of interior spaces }\end{array}$ \\
\hline Blending silo (42) & $\begin{array}{l}\text { - Not visually pleasing, needs general cleaning } \\
\text { - Needs general paint work }\end{array}$ \\
\hline Pre-heater (42) & $\begin{array}{l}\text { - Not visually pleasing, workable structure } \\
\text { - Rusty steel }\end{array}$ \\
\hline Raw mill (42) & $\begin{array}{l}\text { - Not visually pleasing, rusty steel } \\
\text { - Needs general cleaning }\end{array}$ \\
\hline Oven & $\begin{array}{l}\text { - Not visually pleasing, rusty steel } \\
\text { - Needs general cleaning }\end{array}$ \\
\hline Clinker silo (44) & $\begin{array}{l}\text { - Visually pleasing, needs general cleaning } \\
\text { - Needs extensive paint work, freestanding silos }\end{array}$ \\
\hline Clinker silos extension & $\begin{array}{l}\text { - Not visually pleasing, needs general cleaning } \\
\text { - Broken asbestos }\end{array}$ \\
\hline Clinker silos (44) & $\begin{array}{l}\text { - Not visually pleasing, needs general cleaning } \\
\text { - Needs extensive paint work, freestanding silo }\end{array}$ \\
\hline Cement mill (46) & $\begin{array}{l}\text { - Not visually pleasing, needs general cleaning } \\
\text { - Very dusty, broken asbestos }\end{array}$ \\
\hline Cooler(45) & $\begin{array}{l}\text { - Broken concrete blocks, not visually pleasing } \\
\text { - Needs general cleaning, very dusty }\end{array}$ \\
\hline Cement mill (47) & $\begin{array}{l}\text { - Broken asbestos, visually pleasing } \\
\text { - Quality of interior spaces }\end{array}$ \\
\hline Raw material feed (37) & $\begin{array}{l}\text { - Broken asbestos, not visually pleasing } \\
\text { - Rusty steel }\end{array}$ \\
\hline
\end{tabular}


Table 3. SWOT analysis

\begin{tabular}{|c|c|c|c|c|}
\hline Indicators & Strength & Weakness & Opportunity & Threat \\
\hline Environmental & $\begin{array}{l}\text { The soil and climate } \\
\text { conditions of Al- } \\
\text { Fuheis are appropri- } \\
\text { ate for agriculture. }\end{array}$ & $\begin{array}{l}\text { There are different } \\
\text { types of contamina- } \\
\text { tion as a result of } \\
\text { the cement factory's } \\
\text { location. }\end{array}$ & $\begin{array}{l}\text { Use the agricultural } \\
\text { area and achieve } \\
\text { self-sufficiency. }\end{array}$ & $\begin{array}{l}\text { - The cement factory } \\
\text { is a major cause of } \\
\text { pollution. } \\
\text { - Urban encroach- } \\
\text { ment on agricultural } \\
\text { land. }\end{array}$ \\
\hline Economical & $\begin{array}{l}\text { There are light } \\
\text { industries in Al- } \\
\text { Fuheis, such as } \\
\text { various types of } \\
\text { food production. } \\
\text { - There are mul- } \\
\text { tiple heritage sites, } \\
\text { which increase } \\
\text { tourism. }\end{array}$ & $\begin{array}{l}\text { The three main } \\
\text { factories are located } \\
\text { in the south. }\end{array}$ & $\begin{array}{l}\text { Encourage new } \\
\text { public and private } \\
\text { investment. } \\
\text { Enhance the com- } \\
\text { petitiveness of the } \\
\text { tourism sectors and } \\
\text { develop and revi- } \\
\text { talize the tourism } \\
\text { area. }\end{array}$ & $\begin{array}{l}\text { Low wages and } \\
\text { high cost of living. } \\
\text { - Narrow streets } \\
\text { negatively affect } \\
\text { economic expan- } \\
\text { sion in the region. } \\
\text { - The lack of invest- } \\
\text { ment facilities. }\end{array}$ \\
\hline Social & $\begin{array}{l}\text { Sufficient facilities } \\
\text { such as schools, } \\
\text { restaurants, and } \\
\text { shops. } \\
\text { - The Al-Fuheis festi- } \\
\text { val is held annually. } \\
\text { - The most common } \\
\text { age is about } 20 \\
\text { years. }\end{array}$ & $\begin{array}{l}\text { Insufficient open } \\
\text { spaces. } \\
\text { - There are no pe- } \\
\text { destrian crosswalks } \\
\text { on the roads. } \\
\text { - The lack of colleges } \\
\text { and universities. } \\
\text { - The lack of green } \\
\text { areas, activities, } \\
\text { and entertainment } \\
\text { zones. } \\
\text { The lack of profes- } \\
\text { sional centers. }\end{array}$ & $\begin{array}{l}\text { Provide a large } \\
\text { park. } \\
\text { - Create educational } \\
\text { institutions for the } \\
\text { community. } \\
\text { - Provide appropriate } \\
\text { youth and entertain- } \\
\text { ment centers. }\end{array}$ & $\begin{array}{l}\text { The possibility of } \\
\text { growth in the crime } \\
\text { rate. } \\
\text { - The possibility of } \\
\text { growth in illiteracy } \\
\text { and unemployment. } \\
\text { - The lack of paths } \\
\text { for pedestrians, } \\
\text { which results in } \\
\text { unsafe pedestrian } \\
\text { crossings for adults } \\
\text { and children. }\end{array}$ \\
\hline
\end{tabular}

\section{a) Greenfield}

The new structure is a witness to the struggle of the community and how negative memories were converted to positive ones, returning AlFuheis to its agricultural nature, which existed before the industrial revolution. Table 4 shows the land use analysis.

\section{b) Open space and recreation}

Al-Fuheis suffers from a lack of open spaces and recreational facilities. Most of the community members are aged around 20 years, which is why they need a space that is equipped for various activities. Offering recreation spaces improves the community's attitude and increases the social interaction between its members. Table 5 shows the land use analysis.

c) Cultural space

The main event at Al-Fuheis, which takes place every year, is the 9-day Al-Fuheis Festival. It includes musical concerts, poetry recitals, art exhibitions, and dance performances, which reflect the community's culture and identity. The place in which the festival is currently held at does not accommodate all of the attendees, which means that the transformation of the factory can enhance the social life in Al-Fuheis. Furthermore, it can be utilized for special occasions. Table 6 shows the land use analysis.

Table 4. The greenfield's enhanced values

\begin{tabular}{|c|c|}
\hline Value & How to enhance it \\
\hline Environmental value & $\begin{array}{l}\text { - Value that will be affected mostly in a positive way. } \\
\text { - The contamination will decrease and almost disappear. } \\
\text { - Al-Fuheis will return to its agricultural roots. }\end{array}$ \\
\hline Economic value & $\begin{array}{l}\text { - Job opportunities for the local community and positive production to fulfill their needs. } \\
\text { - Use the agricultural area and achieve self-sufficiency. }\end{array}$ \\
\hline Social value & $\begin{array}{l}\text { - The life quality will improve. } \\
\text { - The social health will improve. } \\
\text { - By providing jobs for the local people, their feeling of belonging for the place will increase. }\end{array}$ \\
\hline
\end{tabular}


Table 5. The open space and enhanced recreational values

\begin{tabular}{|l|l|}
\hline \multicolumn{1}{|c|}{ Value } & \multicolumn{1}{c|}{ How to enhance it } \\
\hline Environmental value & $\begin{array}{l}\text { - Transforming the contaminated factory to an open space will clean the environment, and its } \\
\text { impact will extend to the urban context. }\end{array}$ \\
\hline Social value & $\begin{array}{l}\text { - The main impact of the transformation is that it will improve the social life, change people's } \\
\text { attitudes, and increase the social interaction between the members of the community. This } \\
\text { space will be a refuge for youth, instead of circles. }\end{array}$ \\
\hline Economic value & $\begin{array}{l}\text { - It is not the main aim, but nominal fees may eventually be required. The fees will be used for } \\
\text { maintenance to ensure the sustainability of the park. }\end{array}$ \\
\hline $\begin{array}{l}\text { Opening restaurants and cafés will produce output for the park. } \\
\text { Create various job opportunities. }\end{array}$
\end{tabular}

Table 6. The cultural space's enhanced values

\begin{tabular}{|l|l|}
\hline \multicolumn{1}{|c|}{ Value } & \multicolumn{1}{c|}{ How to enhance it } \\
\hline Social value & $\begin{array}{l}\text { - This place will represent the social life and culture of the community and increase the social } \\
\text { interactions between members. It will be a center for the young generation's activities. }\end{array}$ \\
\hline Economic value & $\begin{array}{l}\text { - Require nominal fees. The fees will be used for maintenance to ensure the sustainability of the } \\
\text { space. }\end{array}$ \\
\hline Environmental value & - Create job opportunities. \\
\hline
\end{tabular}

\section{d) Light industry associations}

Many women in Al-Fuheis founded special associations for the production of various goods. The transformation of the cement factory from heavy to light industry erases the dark memories of the place while preserving its industrial identity. Table 7 shows the land use analysis.

\section{Provide land use alternatives to engage the local community decision-making}

The questionnaire is a tool that answers the different questions relative to the research and helps in making the best decisions for the regeneration of the brownfield site according to the community's desires. The questionnaire consists of four main sections (see Appendix A). The purposive sample that was chosen for this study includes 377 residents of Al-Fuheis. The sample size was influenced by many factors (see Table 8 ).

\section{RESULTS AND DISCUSSIONS}

The questionnaire analysis includes three main parts.

- Indication of the locals' participation percentage (social value).

The most important part of the questionnaire is the locals' opinion about regeneration and the appropriate usages. Around $93.1 \%$ of the residents are for changing the former usage. The proposed

Table 8. Factors used to calculate the sample size

\begin{tabular}{|l|c|}
\hline Population size & 20,000 \\
\hline $\begin{array}{l}\text { Confidence interval } \\
\text { (margin of error) }\end{array}$ & $\begin{array}{c}5 \% \\
\text { (the standard in quantitative } \\
\text { research) }\end{array}$ \\
\hline Confidence level & $95 \%$ \\
\hline Sample size & 377 \\
\hline
\end{tabular}

Table 7. The Light industrial/association enhancement values

\begin{tabular}{|l|l|}
\hline \multicolumn{1}{|c|}{ Value } & \multicolumn{1}{c|}{ How to enhance it } \\
\hline Economic value & - Various job opportunities for locals and positive production. \\
\hline Social value & $\begin{array}{l}\text { Represent the social life and increase social interactions. The place will introduce Jordanian } \\
\text { interests and local products. }\end{array}$ \\
\hline Environmental value & - Clean up contaminated areas. \\
\hline
\end{tabular}


new land uses are arranged according to the most demanded with the highest percentage: open space and recreation, cultural space, green field, light industrials and commercial zone.95.2\% of the people want to participate in regeneration in the phase of long time operation. The table shows the percentage of people interested in different maintenance works. See table 9 and figures: 3,4.

- Indication of the impact of urban regeneration on the economical value.

Table 10 and figure 5 indicate the impact of urban regeneration on the economical value. As it can be seen, around $48 \%$ of the landowners accept the idea of investing their lands for an annual profit rate and $27.1 \%$ strongly agree. $46 \%$ of the residents agree that the urban regeneration creates diverse job opportunities for society and $43.6 \%$ strongly agree to this. Additionally, around $48.5 \%$ strongly agree that the urban regeneration provides a new investment, and $40.6 \%$ of citizens agree with this situation. The previous analysis ensures the economical effect of urban regeneration.

- Indication of the impact of urban regeneration on the environmental value.

Table 11 and figure 6 indicate the impact of urban regeneration on the environmental value. As it can be seen, around $95.5 \%$ of the society agrees that the cement factory has a negative impact on the nature of Al-Fuheis agriculture's. 96\% of the residents agree that the cement factory has a negative impact on health. Moreover, around $95.7 \%$ agree that the surrounding contexts of the cement factory need environmental remediation. The previous analysis ensures the environmental effects of urban regeneration.

From the previous analysis, the idea of urban regeneration was strongly accepted by the local community, and $95 \%$ of the residents wanted to participate in the regeneration of the cement

Table 9. Indication of the locals' participation percentage

\begin{tabular}{|c|c|c|c|}
\hline \multicolumn{2}{|c|}{ Indicators } & Frequency & Percentage (\%) \\
\hline \multirow{2}{*}{$\begin{array}{l}\text { Are you with the presence of the } \\
\text { cement factory in Al-Fuheis? }\end{array}$} & Yes & 351 & 93.1 \\
\hline & No & 26 & 6.9 \\
\hline \multicolumn{2}{|c|}{ Total } & 377 & $100 \%$ \\
\hline \multirow{2}{*}{$\begin{array}{l}\text { Are you with the functional trans- } \\
\text { forming of the cement factory? }\end{array}$} & Yes & 351 & 26 \\
\hline & No & 93.1 & 6.9 \\
\hline \multicolumn{2}{|c|}{ Total } & 377 & $100 \%$ \\
\hline \multirow{5}{*}{$\begin{array}{l}\text { If the cement factory has been } \\
\text { reused, what is the most appro- } \\
\text { periate usage? }\end{array}$} & Greenfield & 58 & 15.4 \\
\hline & Open space and recreation & 158 & 41.9 \\
\hline & Cultural space & 83 & 22 \\
\hline & Light industrial/association & 47 & 12.5 \\
\hline & Commercial zone & 31 & 8.2 \\
\hline \multicolumn{2}{|r|}{ Total } & 377 & $100 \%$ \\
\hline \multirow{2}{*}{$\begin{array}{l}\text { If you have a chance to par- } \\
\text { ticipate in reusing the site, would } \\
\text { you participate in the process of } \\
\text { choosing the new usages? }\end{array}$} & Yes & 359 & 95.2 \\
\hline & No & 18 & 4.8 \\
\hline \multicolumn{2}{|c|}{$\begin{array}{ll} & \text { Total } \\
\end{array}$} & 377 & $100 \%$ \\
\hline \multirow{5}{*}{$\begin{array}{l}\text { If you heard about voluntary work } \\
\text { in the maintenance of a building } \\
\text { or an urban space, what is the } \\
\text { type of work that you prefer? }\end{array}$} & Painting & 75 & 19.9 \\
\hline & Removing the garbage & 78 & 20.7 \\
\hline & Watering plants & 88 & 23.3 \\
\hline & Re-designing a space or building & 96 & 25.5 \\
\hline & $\begin{array}{l}\text { Specific Maintenance such as } \\
\text { (electrical, mechanical and so on) }\end{array}$ & 40 & 10.6 \\
\hline \multicolumn{2}{|r|}{ Total } & 377 & $100 \%$ \\
\hline \multirow{4}{*}{$\begin{array}{l}\text { If the cement factory site has } \\
\text { been re used to provide an urban } \\
\text { space that increases the com- } \\
\text { munity interaction, in your opinion } \\
\text { what is the most appropriate } \\
\text { space? }\end{array}$} & Entertainment space & 29 & 7.7 \\
\hline & Cultural festival space & 143 & 37.9 \\
\hline & Parks & 102 & 27.1 \\
\hline & Sports Space & 103 & 27.3 \\
\hline \multicolumn{2}{|c|}{ Total } & 377 & $100 \%$ \\
\hline
\end{tabular}




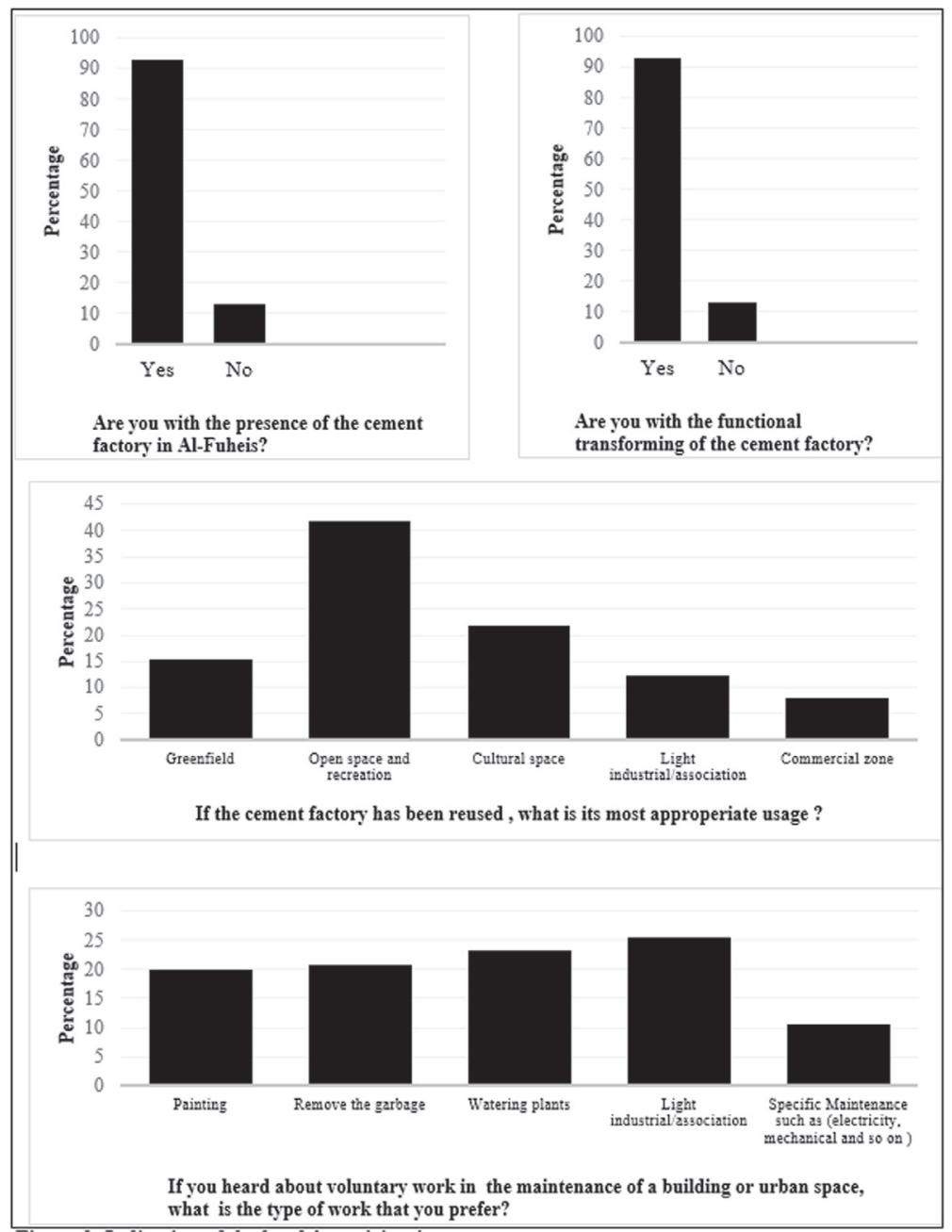

Figure 3. Indication of the locals' participation percentage
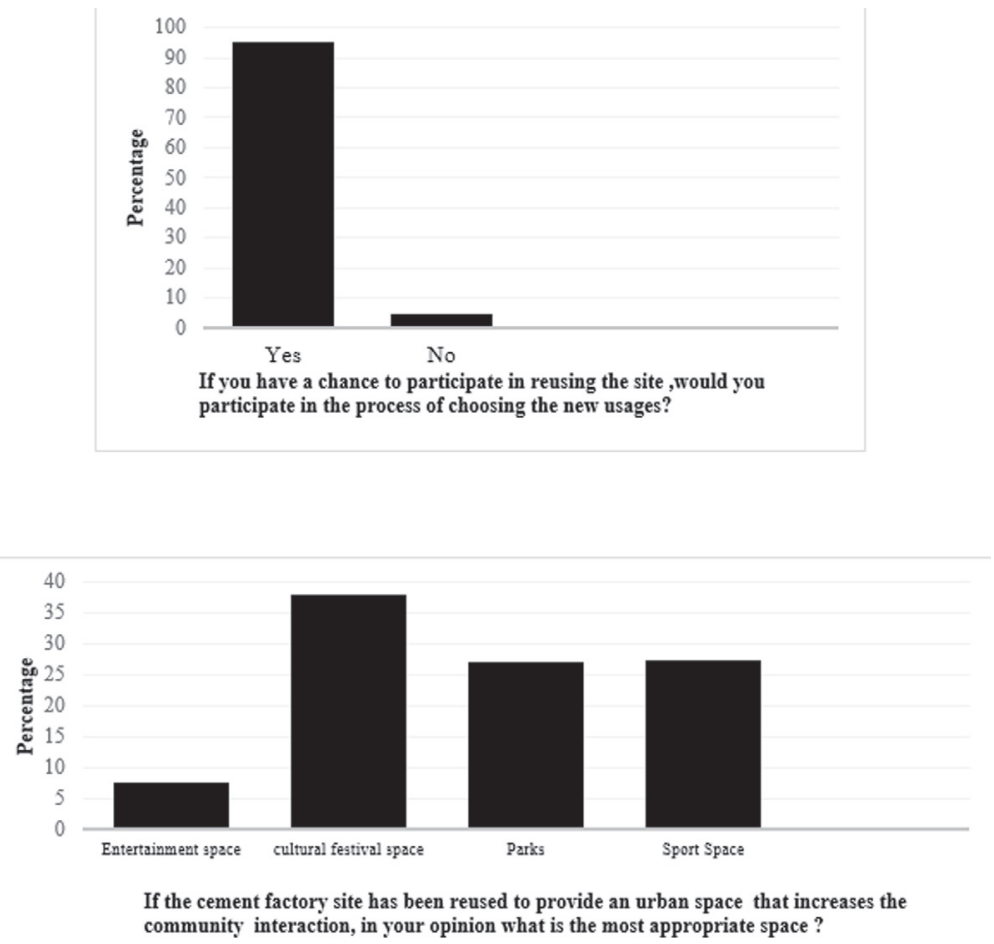

Figure 4. Indication of the locals' participation percentage 
Table 10. Indication of the impact of urban regeneration on the economical value

\begin{tabular}{|c|c|c|c|}
\hline \multicolumn{2}{|c|}{ Indicators } & \multirow{2}{*}{$\begin{array}{c}\text { Frequency } \\
102\end{array}$} & \multirow{2}{*}{$\frac{\text { Percentage }(\%)}{27.1}$} \\
\hline \multirow{5}{*}{$\begin{array}{l}\text { If you are a landowner in the } \\
\text { cement factory, do you agree to } \\
\text { invest your land for an annual } \\
\text { profit rate? }\end{array}$} & Strongly Agree & & \\
\hline & Agree & 181 & 48 \\
\hline & Neutral & 62 & 16.4 \\
\hline & Disagree & 24 & 6.4 \\
\hline & Strongly Disagree & 8 & 2.1 \\
\hline \multicolumn{2}{|c|}{ Total } & 377 & $100 \%$ \\
\hline \multirow{5}{*}{$\begin{array}{l}\text { The urban regeneration (re use } \\
\text { the site) creates diverse job } \\
\text { opportunities for society? }\end{array}$} & Strongly Agree & 163 & 43.6 \\
\hline & Agree & 172 & 46 \\
\hline & Neutral & 29 & 7.8 \\
\hline & Disagree & 7 & 1.9 \\
\hline & Strongly Disagree & 3 & 0.8 \\
\hline \multicolumn{2}{|c|}{ Total } & 377 & $100 \%$ \\
\hline \multirow{5}{*}{$\begin{array}{l}\text { The urban regeneration (re use } \\
\text { the site) provides different } \\
\text { investment opportunities? }\end{array}$} & Strongly Agree & 183 & 48.5 \\
\hline & Agree & 153 & 40.6 \\
\hline & Neutral & 35 & 9.3 \\
\hline & Disagree & 4 & 1.1 \\
\hline & Strongly Disagree & 2 & 0.5 \\
\hline \multicolumn{2}{|c|}{ Total } & 377 & $100 \%$ \\
\hline
\end{tabular}

Source: (Authors, 2017)

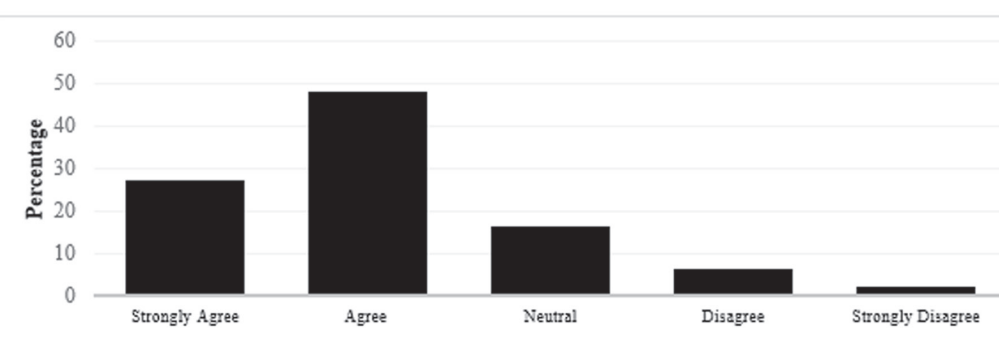

If you are a landowner in the cement factory, do you agree to invest your land for an annual profit rate?

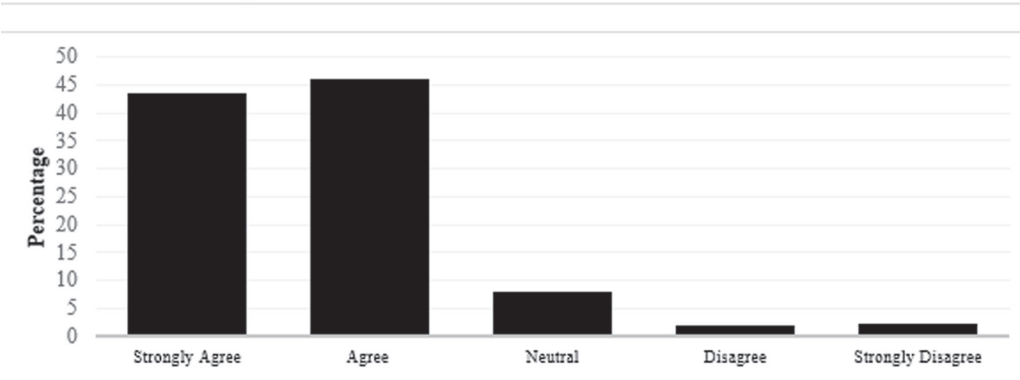

The urban regeneration (re use the site) creates diverse job opportunities for society?

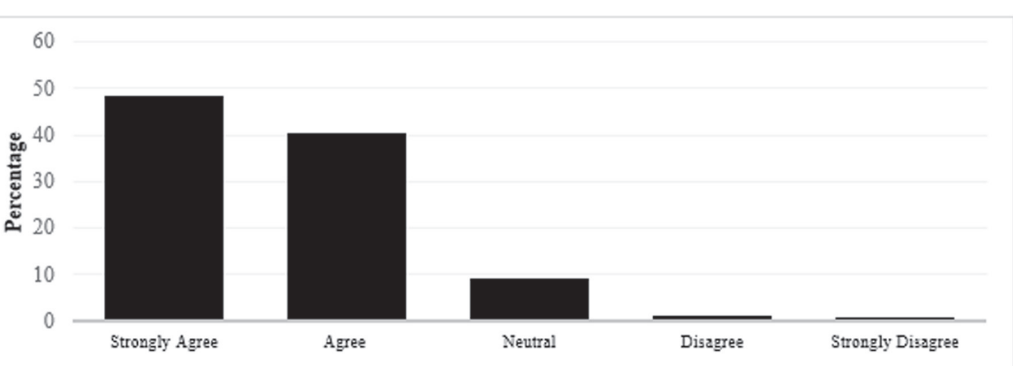

The urban regeneration (re use the site) provides different investment opportunities?

Figure 5. Indication of the impact of urban regeneration on the economical value 
Table 11. Indication of the impact of urban regeneration on the environmental value

\begin{tabular}{|c|c|c|c|}
\hline \multicolumn{2}{|c|}{ Indicators } & Frequency & Percentage (\%) \\
\hline \multirow{5}{*}{$\begin{array}{l}\text { The existence of the cement } \\
\text { factory has a negative impact } \\
\text { on the nature of the agricultural } \\
\text { Fuheis? }\end{array}$} & Strongly Agree & 235 & 62.5 \\
\hline & Agree & 124 & 33 \\
\hline & Neutral & 15 & 4 \\
\hline & Disagree & 3 & 0.5 \\
\hline & Strongly Disagree & 0 & 0 \\
\hline \multicolumn{2}{|c|}{ Total } & 377 & $100 \%$ \\
\hline \multirow{5}{*}{$\begin{array}{l}\text { The cement factory has a } \\
\text { negative impact on health? }\end{array}$} & Strongly Agree & 242 & 64.2 \\
\hline & Agree & 120 & 31.8 \\
\hline & Neutral & 11 & 2.9 \\
\hline & Disagree & 4 & 1.1 \\
\hline & Strongly Disagree & 0 & 0 \\
\hline \multicolumn{2}{|c|}{ Total } & 377 & $100 \%$ \\
\hline \multirow{5}{*}{$\begin{array}{l}\text { The surrounding contexts } \\
\text { of the cement factory need } \\
\text { environmental remediation? }\end{array}$} & Strongly Agree & 240 & 63.8 \\
\hline & Agree & 120 & 31.9 \\
\hline & Neutral & 11 & 2.9 \\
\hline & Disagree & 6 & 1.4 \\
\hline & Strongly Disagree & 0 & 0 \\
\hline \multicolumn{2}{|c|}{ Total } & 377 & $100 \%$ \\
\hline
\end{tabular}

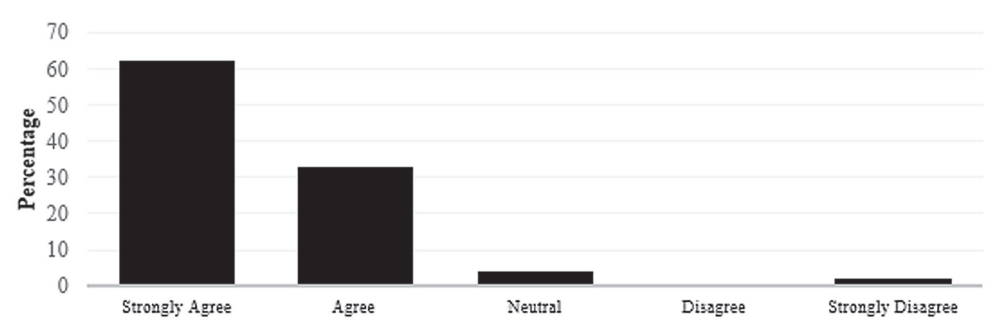

The existence of the cement factory has a negative impact on the nature of the agricultural Fuheis?

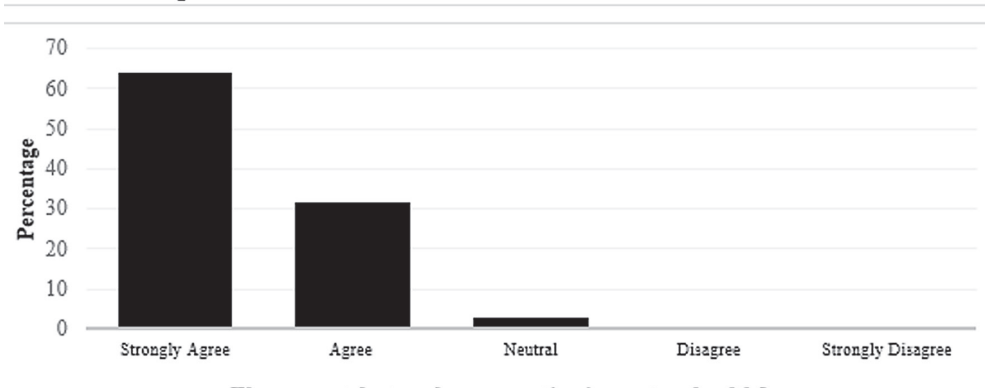

The cement factory has a negative impact on health?

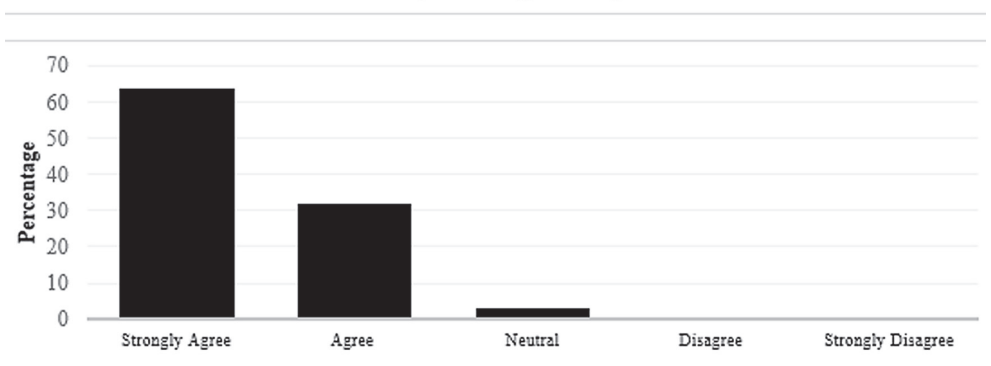

The surrounding contexts of the cement factory need environmental remediation?

Figure 6. Indication of the impact of urban regeneration on the environmental value 
factory. Most of the community favored reusing the site as a recreational and cultural spot.

They strongly agree that the brownfield urban regeneration has a role in encouraging social, environmental, and economic values. The characteristics of the sample (gender, employment field, and age) had no impact on the judgment of the respondents.

Figure 7 shows the percentages of the proposed land uses that are used in re-zoning the master plan.

The proposed master plan for the cement factory is divided into two main parts: the factory core and the boundary zone. The factory core is converted into a cultural-industrial park. It consists of three main zones: food processing zone, a cultural zone, and a public park. The culturalindustrial park is separated from the surroundings and gated. There are three gates: the main gate, a gate for the industrial zone, and a gate for the recreational and cultural zones. The industrial zone is a professional college that consists of a food processing facility, research center, educational facility, green houses, and greenspace. The boundaries of the cement factory consist of facility zones: mix used, commercial, housing, and hospital. The south edge of the cement factory is replaced by a commercial zone, which allows the services zone to be distributed from the downtown of Al-Fuheis and reduce the congestion there. According to the SWOT analysis, Al-Fuheis also needs a hospital. The residential zones will be re-planned at a later phase and are preceded by the facilities. The street network is also re-planned, and new streets are proposed. Two nodes are planned: the first one is at the access to the Shaker circle; the other one is at the cultural park. These circles complete the network identity of Al-Fuheis. The new street network will serve the future expansion of the city. See figure 8.

After the zoning and design guideline plans, the preliminary master plan is prepared, as shown in Figure 9.

The regeneration scenario is successful in both economic and environmental fields. It is summarized in the following two diagrams (see figure 10,11). These diagrams facilitate the careful application of the regeneration process.

The proposed land uses' percentage by the questionnaire.
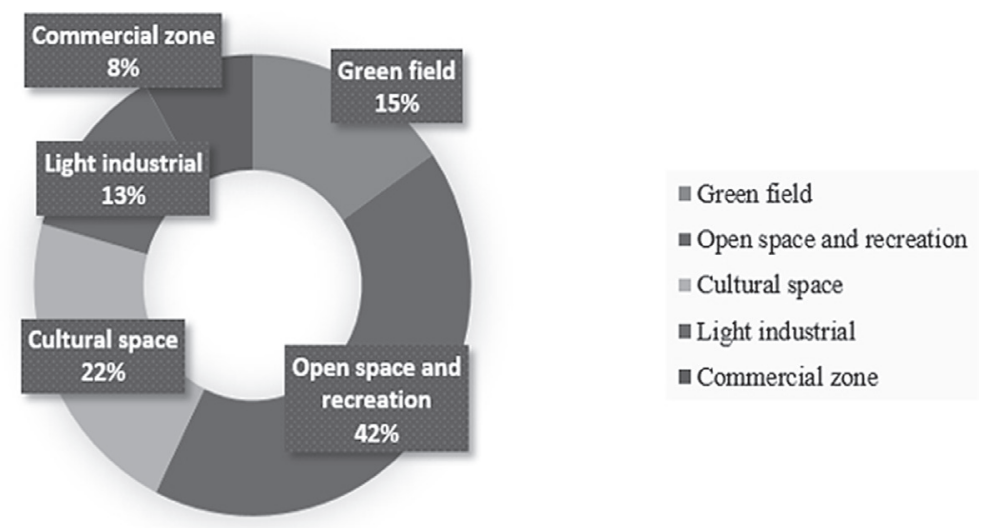

Figure 7. Proposed land use percentages from the questionnaire

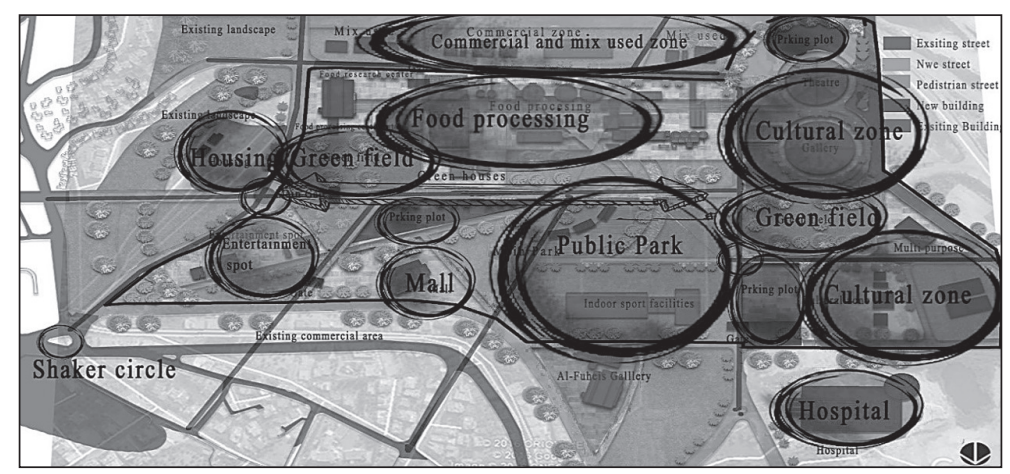

Figure 8. Zoning master plan 


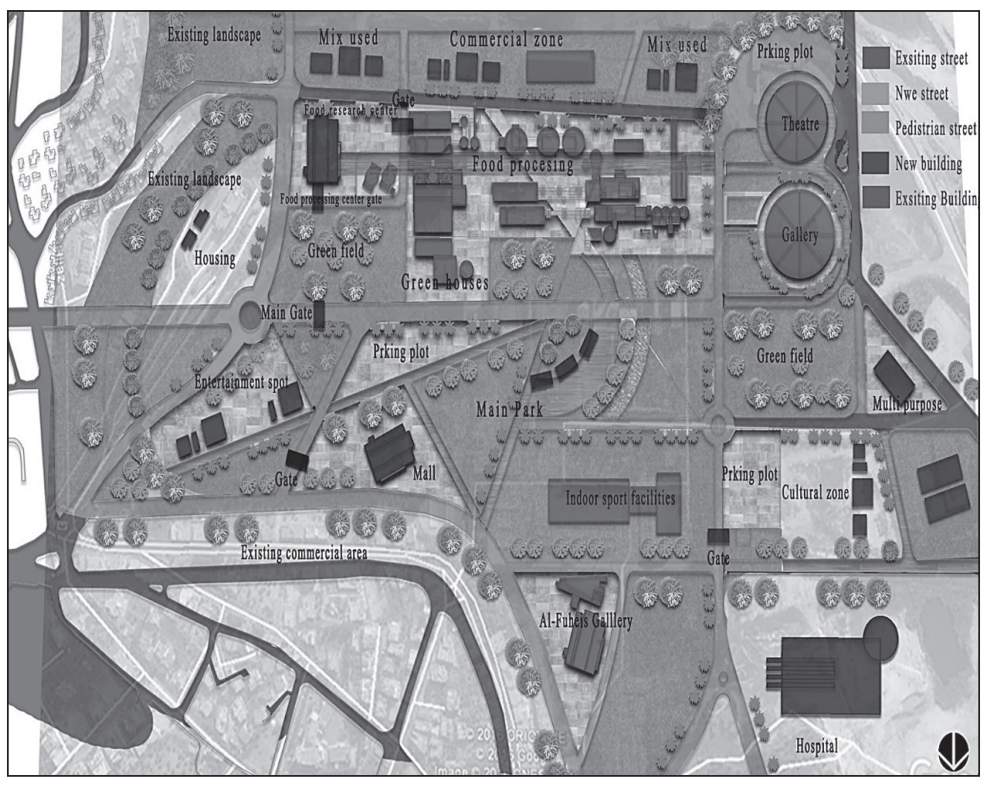

Figure 9. The preliminary master plan

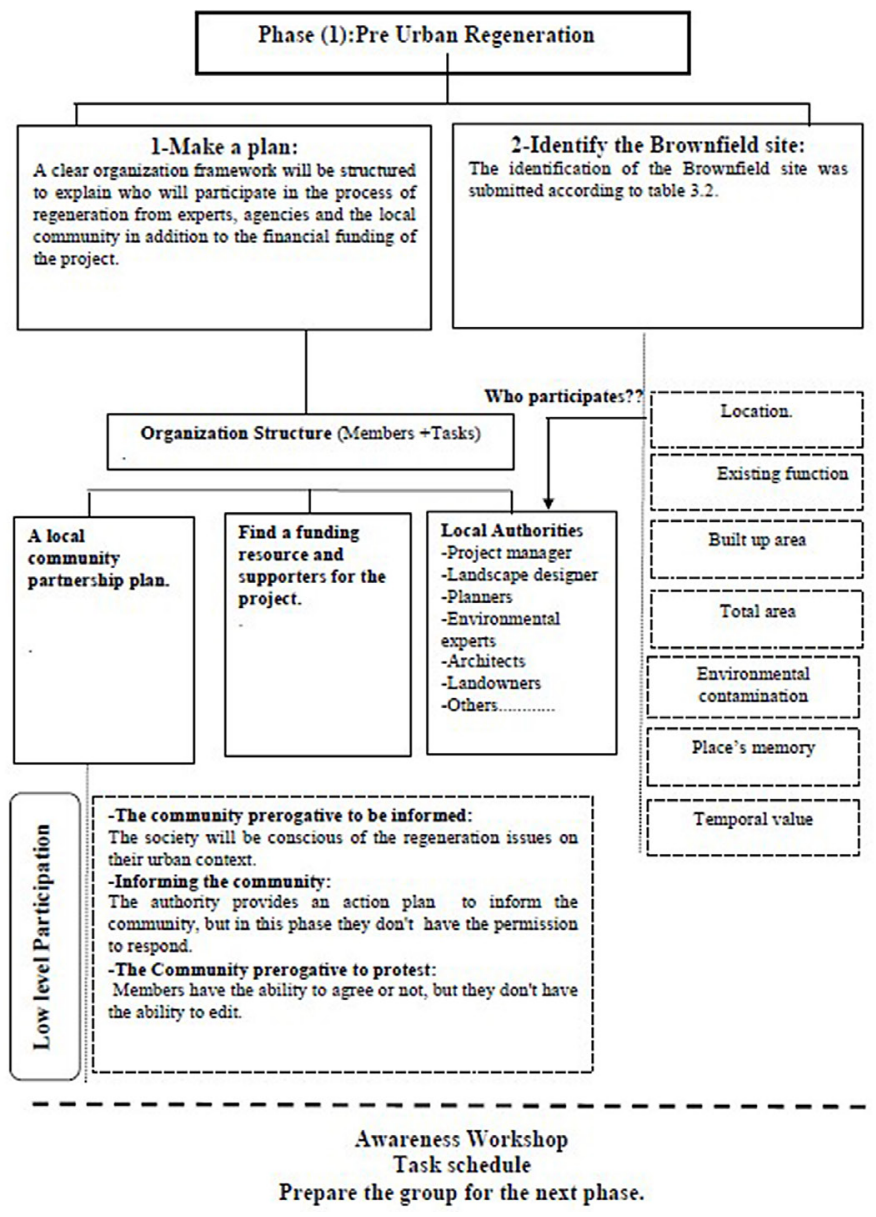

Figure 10. First phase structure

In order to ensure sustainability of the project, a maintenance schedule was prepared by a specialized group. According to the previously mentioned questionnaire, the local community has been involved in painting, removing garbage, re-designing spaces and buildings, as well as specific maintenance (electrical, mechanical, etc.). Table 12 provides a basic schedule. 


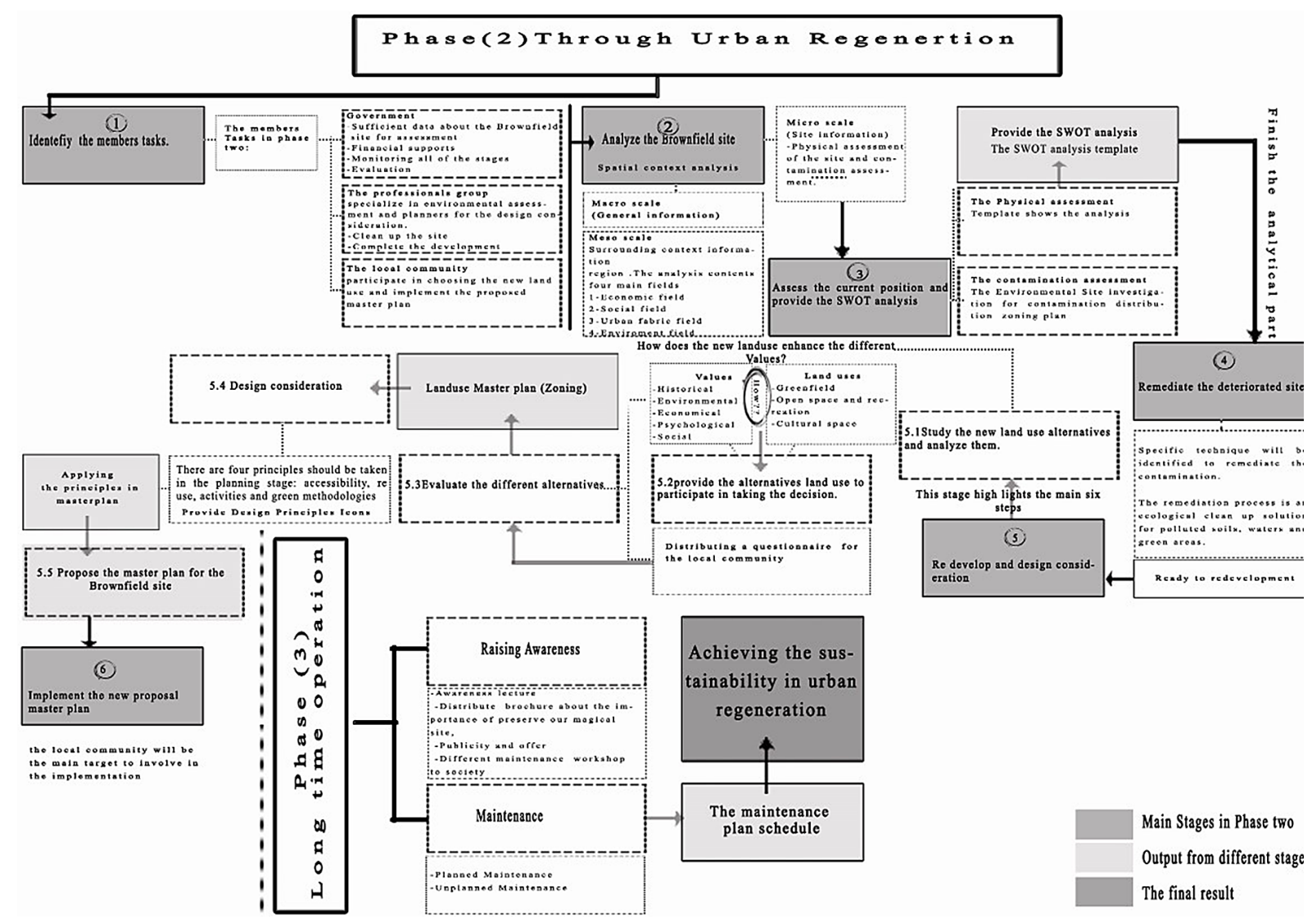

Figure 11. The second and third phases structure

\section{CONCLUSIONS}

Although Brownfield has many disadvantages, it has a potential for the growth of economy and the urban regeneration. It needs a clear framework to remediate contamination and restore life to the deteriorated site.

Three values should be involved in the brownfield regeneration, these values are:

\section{Social values:}

The social values can be enhanced through encouraging the community's responsibility in taking the decision of re-using the site, creating more sight attraction places that permit the public to show their creativity, create cultural events, provide local facilities and introduce a flexible space for multi events.

\section{Economic values:}

They can be enhanced through creating job opportunities, encouraging investments and increasing the income. As the research mentioned before, if the planner introduces a park, the economic value could be enhanced by requiring nominal fees. The fees will be used in maintenance to insure the park's sustainability. Reducing the energy consumption in the regeneration process is the main dimension to achieve the economical sustainability.

\section{Environmental values:}

They can be enhanced through converting the deteriorated site to green space that will contribute to creating a clean environment with no contamination, conserving fertile soil and natural resources by remediation and decreasing the gas emission to help in global warming.

For a long period, some elements will be exposed to deterioration. Wherefore, the building needs careful planning strategies to preserve them and prevent the return of a Brownfield site as a result of neglect.

\section{Acknowledgment}

The completion of the research would not be possible without the participation from the society. This research depended on the local society participation in the urban regeneration process. Next, we would like to thank Al-Fuheis municipality by providing sufficient information to complete this research. 
Table 12. Maintenance schedule

\begin{tabular}{|c|c|c|c|}
\hline Task & $\begin{array}{l}\text { Timeframe } \\
\text { (daily, monthly, annually, } \\
\text { yearly, or as needed) }\end{array}$ & Repetition & $\begin{array}{l}\text { Participating members from the } \\
\text { community (experts, park keepers, } \\
\text { architects, and planners) }\end{array}$ \\
\hline \multicolumn{4}{|l|}{$\begin{array}{l}\text { Building and Amphitheater (each } \\
\text { building will have a schedule according } \\
\text { to its requirements). }\end{array}$} \\
\hline Clean inside and outside the building. & Weekly & 7 & $\begin{array}{l}\text { Park keepers } \\
\text { Local community }\end{array}$ \\
\hline Replace the garage. & Weekly & 7 & Park keepers \\
\hline Clean the windows. & Weekly & 1 & Park keepers \\
\hline $\begin{array}{l}\text { Check the mechanical systems (water } \\
\text { pumps, heating and cooling system). }\end{array}$ & Monthly & 1 & Experts \\
\hline Check the lighting system. & Weekly & 1 & Experts \\
\hline Check the security. & Weekly & 7 & Park keepers \\
\hline Remove graffiti. & Weekly & 1 & Park keepers \\
\hline Check the furniture. & Weekly & 1 & Park keepers \\
\hline $\begin{array}{l}\text { Replace some of the furniture (chairs } \\
\text { and desks). }\end{array}$ & \multicolumn{2}{|c|}{ As needed } & Parks keeper \\
\hline Check the emergency systems. & Monthly & 1 & Expert \\
\hline \multicolumn{4}{|l|}{ Hard landscape } \\
\hline \multicolumn{4}{|l|}{ Paths and street furniture } \\
\hline Replace garbage bags. & Weekly & 7 & Park keepers \\
\hline Clean and wash. & Weekly & 7 & Park keepers \\
\hline Wash seats & \multicolumn{2}{|c|}{ As needed } & Park keepers \\
\hline Check the tiles. & Monthly & 1 & Park keepers \\
\hline Repaint or repave & Yearly & $\begin{array}{c}1 / \\
\text { As needed }\end{array}$ & Park maintenance laborer \\
\hline Eligible to use. & Weekly & 1 & Park maintenance laborer \\
\hline Remove graffiti. & Weekly & 1 & Park keepers \\
\hline Repair/replace & \multicolumn{2}{|c|}{ As needed } & Park maintenance laborer \\
\hline Check the infrastructure. & Monthly & 1 & Park maintenance laborer \\
\hline Repair the pumps & As needed & - & Park maintenance laborer \\
\hline Check and repair the lighting. & Weekly & 1 & Expert \\
\hline Check the signs. & Weekly & 7 & Park maintenance laborer \\
\hline Paint the signs. & Yearly & 1 & Park maintenance laborer \\
\hline Replace seasonal signs & \multicolumn{2}{|c|}{ As needed } & Park keepers \\
\hline Check and repair the street furniture & Monthly & $\begin{array}{c}2 / \\
\text { As needed }\end{array}$ & Park maintenance laborer \\
\hline Remove vandalism & \multicolumn{2}{|c|}{ As needed } & Park keepers \\
\hline Clean parking lots. & Daily & 1 & Park keepers \\
\hline \multicolumn{4}{|l|}{ Soft landscape } \\
\hline Remove the garbage. & Weekly & 1 & Park keepers \\
\hline Water & As needed & - & Park keepers \\
\hline Check the irrigation pumps. & Monthly & 2 & Park maintenance laborer \\
\hline Open/close irrigation & Weekly & As needed & Park keepers \\
\hline Repair and replace the irrigation system & \multicolumn{2}{|c|}{ As needed } & Park maintenance laborer \\
\hline Trim trees. & $\begin{array}{l}\text { Growing season/ } \\
\text { weekly }\end{array}$ & 1 & Park keepers \\
\hline Repaint signs & Yearly & 1 or 2 & Park keepers \\
\hline Aeration, fertilizing, weed control & As needed & $\begin{array}{l}\text { Growing } \\
\text { season }\end{array}$ & Park keepers \\
\hline
\end{tabular}




\section{REFERENCES}

1. Bartsch, C., 2006. Getting Started with Brownfields -- Key Issues and Opportunities: What Communities Need to Know, Washington: NortheastMidwest Institute.

2. Başkaya, A.T., 2010. Ways to sustainable brownfield regeneration in Istanbul. ITU A|Z, 7(2), 74-88.

3. Doerle, J.M., 2012. Economic Perspectives of Brownfield Development in Germany. Stuttgart: City of Stuttgart - Department for Environmental Protection.

4. Farraj, N., Makhamreh, H. \& Kareem , S., 2013. The Pace Maker Rehabiilitation of the Fuheis cement factoryStudents. Unpublished Bachelor Dissertation, University of Jordan. Amman: s.n.

5. Fatemi, M.N. \& Rahman, T., 2015. 4Regeneration of the Hazaribagh urban brownfield: An imperative for Dhaka's sustainable urban development. Urbani izziv, 132-145.

6. Folić, N.K. \& Perovic, S., 2012. Brownfield regeneration - imperative for sustainable urban develop- ment. GRAĐEVINAR, 373-383.

7. Hua, G. \& Kang, C., 2007. Brownfield Redevelopment Toward Sustainable Urban Land Use in China. Chinese Geographical Science, 128-134.

8. Lafarge, 2017. Lafarge in Jordan-About us. [Online] Available at: http://www.lafarge.com.jo/wps/portal/jo/en/1_1-Lafarge_in_Jordan

9. Loures, L. \& Panagopoulos, T., 2007. Sustainable reclamation of industrial areas in urban landscapes. Sustainable Development and Planning, 102(3), 791-800.

10. Mehdipour, A. \& Nia, H.R., 2013. The Role of Brownfield Development in Sustainable Urban Regeneration. Journal of Sustainable Development Studies, 4(2), 78-87.

11. Walker, S., 2008. Attitudes and Coalitions in Brownfield Redevelopment and Environmental Management.Unpublished Master Dissertation , University of Waterloo. Canada: s.n.

12. Wikipedia, 2017. Fuheis. [Online] Available at: https://en.wikipedia.org/wiki/Fuheis 